\title{
Model Analisis Risiko Bencana Transportasi Bahan Beracun dan Berbahaya Industri di Kabupaten Serang, Provinsi Banten
}

\section{Disaster Risk Analysis Model for Transportation of Industrial Hazardous Materials in Serang Regency, Banten Province}

\author{
PRIHARTANTO, AKHMADI PUGUH RAHARJO, QORIATU ZAHRO \\ Pusat Teknologi Reduksi Risiko Bencana, Badan Pengkajian dan Penerapan Teknologi \\ Gedung 820 Geostech, Kawasan Puspiptek \\ Email: prihartanto@bppt.go.id
}

\begin{abstract}
Pulo Ampel Industrial Zone in Serang Regency is an industrial zone with a high level of threat from a technological hazard. One possible route this threat can be manifested is in the form of explosion potential from the storage and transport tanks of toxic and dangerous materials e.g. Ethylene and Butadiene gases. Within the framework of disaster risk reduction, disaster risk analysis is carried out which includes the analysis of threats and vulnerabilities along the path of transport of these hazardous materials. To determine the level of explosion hazard, due to the occurrence of transportation accidents, modeling using ALOHA® (Areal Locations of Hazardous Atmospheres) software, which was developed by the United States Environmental Protection Agency (US EPA), was carried out. The model used in this study uses the BLEVEs (Boiling Liquid Expanding Vapor Explosions) scenario during gas transportation using ISO Tank, which represents the worse possible scenario. Meanwhile, disaster vulnerability analysis is calculated based on social vulnerability aspect which includes population density and vulnerable group parameters by utilizing the scoring method in accordance to Head of BNPB Decree No.2 of 2012. Based on the hazard and vulnerability level, disaster risk maps are obtained along the Ethylene and Butadiene transport lines covering the information related to the area of the explosion which intersected with population settlement in Serang Regency, Banten Province.
\end{abstract}

Keywords: risk reduction, trasportation, hazardous materials, vulnerabilities, explotion

\begin{abstract}
ABSTRAK
Zona Industri Pulo Ampel di Kabupaten Serang merupakan zona industri dengan ancaman bencana kegagalan teknologi yang relatif tinggi. Ancaman bahaya yang dapat ditimbulkan diantaranya berupa potensi ledakan dari tangki-tangki penyimpanan maupun tangki transportasi bahan berbahaya dan beracun (B3) terutama gas Etilena maupun Butadiena. Dalam rangka pengurangan risiko bencana, maka dilakukanlah analisis risiko bencana terhadap tangki transportasi B3 yang meliputi analisis ancaman dan kerentanan di sepanjang jalur transportasi B3 tersebut. Untuk menentukan salah satu tingkat bahaya yang berupa ledakan akibat kecelakaan transportasi gas dilakukanlah pemodelan dengan menggunakan perangkat lunak modeling ALOHA® (Areal Locations Of Hazardous Atmospheres) yang dikembangkan oleh United States Environmental Protection Agency (US EPA). Model yang digunakan di dalam kajian ini menggunakan skenario ledakan terburuk berupa skenario BLEVEs (Boiling Liquid Expanding Vapor Explosions) pada saat transportasi gas menggunakan ISO Tank. Sementara analisis kerentanan bencana dihitung berdasarkan aspek kerentanan sosial yang meliputi parameter kepadatan penduduk dan kelompok rentan dengan menggunakan metode skoring sesuai Perka BNPB No. 2 Tahun 2012. Berdasarkan tingkat bahaya dan kerentanan tersebut diperolehlah peta risiko bencana di sepanjang jalur transportasi gas Etilena dan Butadiena yang meliputi informasi terkait luas area permukiman penduduk terdampak ledakan di Kabupaten Serang, Provinsi Banten.
\end{abstract}

Kata kunci: pengurangan risiko, transportasi, bahan beracun dan berbahaya, kerentanan, ledakan

\section{PENDAHULUAN}

Aktivitas industri pada hakikatnya merupakan bagian dari upaya manusia untuk mencapai kemajuan dan kemakmuran. Seiring dengan semakin berkembangnya skala industri maupun teknologi yang digunakannya, risiko kegagalan teknologi yang terdapat di dalam lingkungan industri juga akan semakin meningkat.

United Nation of International Strategies for Disaster Reduction (UNISDR) mendefinisikan kegagalan teknologi sebagai bahaya yang berasal dari kondisi teknologi atau industri, termasuk kecelakaan, prosedur berbahaya, 
kegagalan infrastruktur atau kegiatan manusia tertentu, yang dapat menyebabkan hilangnya nyawa, cedera, penyakit atau dampak kesehatan lainnya, kerusakan properti, hilangnya mata pencaharian dan layanan, sosial dan ekonomi gangguan, atau kerusakan lingkungan ${ }^{(1)}$.

Badan Nasional Penanggulangan Bencana (BNPB) dalam Perka No. 4 tahun 2008 mendefinisikan kegagalan teknologi sebagai kejadian yang diakibatkan oleh kesalahan desain, pengoperasian, kelalaian dan kesengajaan manusia dalam menggunakan teknologi dan atau industri ${ }^{(2)}$. Bencana industri yang merupakan bagian technological hazard didefinisikan sebagai bahaya yang berasal dari kecelakaan teknologi atau industri, prosedur berbahaya, kegagalan infrastruktur atau aktivitas manusia tertentu, yang dapat menyebabkan hilangnya nyawa atau cedera, kerusakan properti, gangguan sosial dan ekonomi atau kerusakan lingkungan ${ }^{(3)}$. Bahaya yang ditimbulkan adalah kebakaran, ledakan, pelepasan racun dan kerusakan lingkungan.

Kejadian bencana industri, yang merupakan salah satu bentuk bencana kegagalan teknologi, kemungkinan memberikan efek lain dari pelepasan bahan berbahaya dan beracun secara tidak disengaja, termasuk akumulasi progresif bahan tersebut pada tanaman, hewan, ikan atau seluruh ekosistem ${ }^{(4)}$. Dalam konteks bencana industri jenis-jenis ancaman dapat dilihat dari tiga jenis bencana yaitu:

a. Kecelakaan dan pelepasan radiasi radionuklida atau radiasi,

b. Pelepasan zat kimia secara tidak disengaja ke lingkungan.

c. Aktivitas yang bisa menyebabkan pelepasan zat biologis atau organisme.

Kerangka kerja Sendai yang disepakati di Jepang pada tanggal 18 Maret 2015 untuk pengurangan risiko bencana 2015-2030 telah menempatkan bencana buatan manusia sebagai bagian penting dalam upaya pengurangan risiko bencana. Hingga tahun 2016, kerugian yang ditimbulkan akibat bencana alam dan bencana buatan manusia di dunia diperkirakan mencapai US\$ 175 miliar, dengan US\$ 9 miliar yang berasal dari bencana buatan manusia $^{(5)}$. Dalam panduan Words in Action (WiA) sebagai dokumen implementasi kerangka Sendai ini, dibahas beberapa fitur penting tentang ancaman buatan manusia, khususnya bencana kegagalan teknologi.

Sebagaimana tercantum dalam dokumen WIA, termasuk di dalam ancaman bencana kegagalan teknologi meliputi bencana-bencana kimia, nuklir dan radiologi, serta transportasi. Ketiga jenis bahaya tersebut didefinisikan berasal dari kondisi teknologi atau industri, prosedur berbahaya, kegagalan infrastruktur atau aktivitas manusia tertentu ${ }^{(5)}$.

Bencana kegagalan teknologi khususnya di sektor industri telah banyak menimbulkan kecelakaan yang menyebabkan ribuan korban di dunia. Perhatian dunia terhadap bencana industri ini meningkat setelah terjadinya insiden Bhopal, Meksiko City, Basel, Seveso, Exxon Valdez dan Chernobyl ${ }^{(4)}$. Dari seluruh bencana kegagalan teknologi, yang terbesar diantaranya adalah kecelakaan Chernobyl dan Fukushima. Bencana kegagalan teknologi terbaru di Fukushima merupakan kondisi darurat radiologis yang telah menelantarkan 165.000 orang dan diperkirakan membutuhkan biaya pemulihan ekonomi sebesar US\$235 miliar ${ }^{(5)}$.

Studi awal yang dilakukan oleh Pusat Studi Kebumian Bencana dan Perubahan Iklim, Institut Teknologi Sepuluh November tahun 2013 menunjukkan bahwa enam Provinsi di Pulau Jawa memiliki kerentanan penduduk terhadap ancaman bencana kegagalan teknologi ${ }^{(6)}$, salah satunya Provinsi Banten. Dua Kabupaten/Kota yang terdapat di Provinsi Banten memiliki ancaman bahaya yang besar akibat keberadaan industri-industri petrokimia yaitu Kabupaten Serang $^{(7)}$ dan Kota Cilegon ${ }^{(8)}$. Salah satu Kecamatan yang memiliki potensi ancaman bencana kegagalan teknologi yang tinggi di sektor industri di Kabupaten Serang adalah Kecamatan Pulo Ampel. Ancaman bahaya yang ditimbulkan dari kegiatan industri di Kecamatan ini tidak saja ditimbulkan dari kegiatan di dalam indutri namun dapat pula dari transportasi bahan beracun dan berbahaya.

Sejumlah besar bahan berbahaya secara rutin ditransportasikan dari dan menuju ke lokasi industri di banyak negara di dunia. Bahan utama yang diangkut pada umumnya berupa gas alam dan minyak bumi, termasuk di dalamnya turunannya berupa LPG, bensin dan senyawa hidrokarbon lainnya. Moda transportasi pada umumnya berupa kapal laut, kendaraan darat (jalan), kereta api dan jalur pipa. Rute transportasi tersebut dapat saja melintasi zona permukiman padat penduduk dengan risiko terjadinya kecelakaan transportasi mengikuti frekuensi tertentu ${ }^{(9)}$.

Survei historis menunjukkan bahwa hampir $40 \%$ dari semua kecelakaan besar terjadi selama fase transportasi ${ }^{(10)}$. Lebih lanjut, berdasarkan survei historis lain yang bersumber dari 1932 kali kejadian kecelakaan transportasi pengangkutan bahan berbahaya dan beracun melalui jalan raya maupun kereta api, diketahui bahwa hampir $75 \%$ dari kejadian tersebut disebabkan oleh tabrakan antar kendaraan maupun tergelincirnya kereta dari rel ${ }^{(11)}$. Penyebab kedua terbesar setelahnya 
disebabkan oleh kegagalan mekanis, peristiwa eksternal dan faktor manusia yang secara Bersama-sama menyumbangkan lebih kurang $18 \%$ dari total kecelakaan.

Dilihat dari lokasinya, kecelakaan di jalan lebih sering terjadi bila dibandingkan dengan kecelakaan pada jalur kereta api yakni $63 \%$ berbanding $37 \%$. Berdasarkan data semua kecelakaan di jalan tersebut, $81 \%$ terjadi pada jalan raya dengan sisanya terjadi pada jalan yang lebih kecil ${ }^{(11)}$.

Dilihat dari frekuensinya, diketahui bahwa setiap satu dari 3,6 kecelakaan diketahui menyebabkan kebakaran, dan setiap satu dari 9,5 kecelakaan menyebabkan ledakan serta setiap satu dari 15 kecelakaan menyebabkan rentetan ledakan api ${ }^{(11)}$.

Dalam makalah ini akan diuraikan tentang potensi bahaya bencana kegagalan teknologi di sektor industri dan transportasi gas B3, terutama berupa zona bahaya yang ditimbulkan oleh ledakan mobil tangki transportasi gas Etilena dan Butadiena.

Paparan gas Etilena dan Butadiena. terhadap manusia dapat mengakibatkan sistem saraf pusat mengalami depresi dan kesulitan pernafasan. Paparan jangka pendek gas ini dapat mengakibatkan gejala mual, muntah, gejala mabuk, warna kulit kebiruan, mati lemas, kejang dan koma.

Gas 1,3-butadiena merupakan gas yang sangat mudah terbakar. Gas ini umumnya disimpan dalam tangki bertekanan pada temperatur $15^{\circ} \mathrm{C}$ dan dapat meledak bila dipanaskan. Pemaparan gas tersebut terhadap manusia dalam jangka panjang dapat menimbulkan kanker dan kerusakan genetik. Campuran gas ini dengan udara dapat menimbulkan ledakan. Bila terpapar langsung pada manusia dapat menimbulkan frosbite.

\section{BAHAN DAN METODE}

\subsection{Waktu dan Tempat}

Secara administratif area penelitian dilakukan di Kabupaten Serang terutama di sepanjang jalur transportasi dari dan menuju ke industri-industri petrokimia yang berada di zona industri Pulo Ampel. Waktu pelaksanaan penelitian dilaksanakan pada bulan Oktober hingga November 2017.

\subsection{Metode Pengkajian Risiko}

Pengkajian risiko bencana merupakan sebuah pendekatan untuk memperlihatkan potensi dampak negatif yang mungkin timbul akibat suatu potensi bencana yang ada ${ }^{(12)}$. Dalam pelaksanaanya, pengkajian risiko menggunakan rumus umum sebagai berikut:

$$
\text { Risiko }=\text { Ancaman } x \frac{\text { Kerentanan }}{\text { Kapasitas }}
$$

Beberapa prinsip dari proses pengkajian risiko bencana yang menjadi pertimbangan proses analisis risiko ${ }^{(12)}$ adalah:

a. Menggunakan data dan segala bentuk rekaman kejadian yang ada, dengan mengutamakan data resmi dari lembaga berwenang;

b. Melakukan integrasi analisis.

Pada penelitian ini hanya dilakukan penentuan ancaman dan kerentanan sosial, namun tidak dilakukan perhitungan kapasitas.

\subsubsection{Bahaya}

Untuk menentukan tingkat bahaya bencana industri akibat kebakaran/ledakan maupun dispersi gas beracun dari kejadian kecelakaan transportasi gas beracun dan berbahaya dibutuhkan pemodelan. Untuk membuat model tersebut digunakan software modeling $\mathrm{ALOHA}^{\circledR}$ (Areal Locations Of Hazardous Atmospheres) Versi 5.4.7, September 2016 yang dikembangkan oleh United States Environmental Protection Agency (US EPA). Model ALOHA ${ }^{\circledR}$ adalah model dispersi udara untuk mengevaluasi pelepasan bahan kimia beracun dan berbahaya ke udara. Input data yang dibutuhkan adalah data atmosferik, dimensi tangki, jenis bahan kimia. Model ini merupakan model dispersi kategori open source dengan variable input yang memadai dan sudah banyak digunakan di industri-industri.

Ledakan tangki ISO diasumsikan dapat terjadi di sepanjang jalur transportasi gas Etilena dan Butadiena dengan probabilitas kejadian yang sama. Ledakan tangki dapat disebabkan oleh kecelakaan lalu lintas maupun akibat kebocoran tangki.

Untuk mendapatkan skenario ledakan terburuk pada saat trasportasi gas menggunakan ISO Tank, digunakan skenario BLEVEs (Boiling Liquid Expanding Vapor Explosions) pada kontainer tangki ISO yang berisi Etilena maupun Butadiena dengan kedua tangki yang terisi sebanyak $80 \%$. Jenis ledakan BLEVEs terjadi ketika tangki bertekanan mengalami rusak, sehingga tekanan tiba-tiba turun ke tekanan atmosferik dan cairan panas mendidih seketika, menghasilkan uap dalam jumlah besar. Kerusakan terjadi oleh gelombang tekanan akibat ekspansi cepat dari uap yang dilepaskan, dan oleh terbangnya pecahan-pecahan bejana tekan dan perpipaan. Jika cairan mudah terbakar, maka cairan dapat menyala dan menghasilkan bola api besar

Hasil pemodelan digunakan untuk menentukan zona potensi bahaya ledakan dan dispersi gas di sepanjang jalur transportasi gas 
beracun dan berbahaya. Input model diperoleh berdasarkan data dan informasi proses yang diperoleh dari beberapa industri berupa jenis fluida dalam tangki, diameter tangki, panjang tangki, volume tangki, wujud fluida, persentase isi tangki dan asumsi massa fluida dalam tangki yang berubah jadi bola api.

Data arah, kecepatan angin, tutupan awal, temperatur udara dan kelembaban relatif diperoleh dari Stasiun Meteorologi Kelas 1 BMKG yang bertempat di Taktakan, Kabupaten Serang untuk tahun pengamatan 2016.

\subsubsection{Kerentanan}

Parameter kerentanan bencana dihitung berdasarkan kerentanan sosial ${ }^{(12)}$. Kerentanan sosial terdiri dari parameter kepadatan penduduk dan kelompok rentan. Kelompok rentan terdiri dari rasio jenis kelamin, rasio kelompok umur rentan, rasio penduduk miskin, dan rasio penduduk cacat ${ }^{(12)}$. Secara spasial, masingmasing nilai parameter didistribusikan di wilayah desa/ kelurahan.

Masing-masing parameter dianalisis dengan menggunakan metode skoring sesuai Perka BNPB No. 2 Tahun 2012 untuk memperoleh nilai skor kerentanan sosial sebagaimana disajikan pada Tabel 1.

Analisis spasial kerentanan dilakukan melalui platform GIS dengan menggunakan perangkat lunak ArcMap ArcGIS versi 10.1. Peta dasar yang digunakan berupa peta batas administrasi bersumber dari peta Rupa Bumi Indonesia yang dikeluarkan oleh BIG skala 1:250.000.

a. Kepadatan penduduk

Kepadatan penduduk merupakan fungsi rasio jumlah penduduk dengan luas wilayah administrasi $\left(\mathrm{km}^{2}\right)$. Data jumlah penduduk didapatkan dari Dinas Kependudukan dan Catatan Sipil Kabupaten Serang penghitungan tengah tahun 2017.

b. Rasio jenis kelamin

Rasio jenis kelamin adalah perbandingan antara jumlah penduduk laki-laki terhadap perempuan. Semakin kecil nilai rasio semakin tinggi tingkat kerentanannya

c. Rasio penduduk umur rentan

Penduduk rentan merupakan penduduk pada usia tidak produktif, yaitu usia $<14$ tahun dan $>65$ tahun. Rasio penduduk usia rentan (dependency ratio) adalah perbandingan penduduk penduduk usia tidak produktif (usia ketergantungan) terhadap penduduk usia produktif. Semakin besar nilai rasio penduduk usia rentan, semakin tinggi tingkat kerentannya.

d. Rasio penduduk miskin

Rasio penduduk miskin menujukkan kerentanan masyarakat secara ekonomi.
Idealnya, penghitungan rasio penduduk miskin didasarkan pada data jumlah penduduk miskin BPS. Namun karena data tersebut tidak didapatkan untuk seluruh wilayah kajian, maka digunakan pendekatan tingkat kesejahteraan, dimana kelompok penduduk pra sejahtera diasumsikan sebagai kelompok penduduk miskin.

e. Rasio penduduk cacat

Rasio penduduk cacat merupakan perbandingan antara penduduk cacat terhadap penduduk yang tidak cacat. Semakin besar nilai rasio penduduk cacat maka semakin besar tingkat kerentanan suatu wilayah. Data penduduk cacat yang digunakan adalah data penduduk cacat yang dikeluarkan oleh BPS. Meskipun data BPS dipandang kurang mutakhir dibandingkan dengan data Dinas Sosial, namun data BPS dipandang lebih mewakili karena data Dinas Sosial hanya mencatat penduduk cacat yang merupakan kelompok PMKS (Penyandang Masalah Kesejahteraan Sosial).

Tabel 1. Parameter penyusun dan pengharkatan kerentanan sosial $^{(12)}$

\begin{tabular}{lcccc}
\hline \multirow{2}{*}{ Parameter } & $\begin{array}{c}\text { Bobot } \\
\text { Ko) }\end{array}$ & \multicolumn{3}{c}{ Kelas } \\
\cline { 3 - 5 } & Rendah & Sedang & Tinggi \\
\hline $\begin{array}{l}\text { Kepatan } \\
\text { Penduduk }\end{array}$ & 60 & $\begin{array}{c}<5 \\
\text { jiwa/ha }\end{array}$ & $\begin{array}{c}5-10 \\
\text { jiwa/ha }\end{array}$ & $\begin{array}{c}>10 \\
\text { jiwa/ha }\end{array}$ \\
\hline $\begin{array}{l}\text { Kelompok } \\
\text { rentan }\end{array}$ & 40 & & & \\
\hline $\begin{array}{l}\text { Rasio } \\
\text { Jenis }\end{array}$ & 10 & $>40$ & $20-40$ & $<20$ \\
$\begin{array}{l}\text { Kelamin } \\
\text { Rasio }\end{array}$ & & & & \\
$\begin{array}{l}\text { Kel.Umur } \\
\text { Rentan }\end{array}$ & 10 & & & \\
$\begin{array}{l}\text { Rasio } \\
\text { Penduduk }\end{array}$ & 10 & $<20$ & $20-40$ & $>40$ \\
miskin & & & & \\
$\begin{array}{l}\text { Rasio } \\
\text { Penduduk }\end{array}$ & 10 & & & \\
Cacat & & & & \\
\hline
\end{tabular}

\subsubsection{Pemetaan Risiko}

Risiko bencana dihitung dengan menggabungkan nilai bahaya dan kerentanan. Kalkulasi ini dilakukan secara spasial sehingga dihasilkan peta risiko dan nilai risiko yang dapat digunakan untuk analisis risiko berikutnya. Peta risiko seluruh provinsi disajikan dalam skala 1:350.000 dengan mengikuti kaidah kartografi. Kelas risiko dibagi menjadi 3 yaitu risiko tinggi, sedang dan rendah.

Penduduk yang berisiko terpapar bahaya bencana transportasi bahan berbahaya industri berdiam secara mengelompok pada kawasankawasan permukiman saja. Kawasan-kawasan 
yang tidak dihuni, bukan merupakan kawasan berisiko meskipun kawasan tersebut memiliki bahaya. Atas dasar asumsi ini maka peta risiko dihasilkan dari penampalan dengan peta permukiman di sepanjang jalur transportasi gas berbahaya.

\section{HASIL DAN PEMBAHASAN}

\subsection{Analisis Bahaya}

\subsubsection{Skenario Ledakan Tangki Transportasi Gas}

Untuk melakukan analisis bahaya akibat ledakan tangki transportasi gas B3, maka perlu dibangun skenario awal ledakan tangki yang meliputi jalur tranportasi gas, karakteristik bahaya dari gas B3 yang diangkut, skenario ledakan dan model ledakan.

\section{a. Jalur Transportasi Gas}

Transportasi gas di sekitar zona industri Kabupaten Serang sebagian besar untuk menyuplai kebutuhan gas untuk industri-industri petrokimia yang berada di zona industri Pulo Ampel, terutama gas Etilena dan Butadiena. Kedua jenis gas tersebut dikategorikan sebagai bahan beracun dan berbahaya (B3).

Transportasi gas beracun dan berbahaya di Kabupaten Serang dari dan ke zona industri Kecamatan Pulau Ampel dilakukan dengan menggunakan kendaraan kontainer ISO Tank. Transportasi tersebut sebagian besar melalui jalur sebagai berikut:

1) Jalan provinsi dari Kecamatan Pulo Ampel-Kecamatan Bojonegara

2) Jalan tol dari Kecamatan Kramat Watu, Ciruas, Kragilan, Kibin dan Cikande

b. Karakteristik Bahaya Gas yang Diangkut Dua jenis gas yang sering diangkut dengan kontainer ISO Tank melalui jalur jalan Pulo Ampel-Bojonegoro dan jalan tol Jakarta-Merak adalah gas etilena dan 1,3-butadiena. Gas etilena atau ethylene $\left(\mathrm{C}_{2} \mathrm{H}_{4}\right)$ merupakan gas yang disimpan dalam tangki bertekanan pada temperatur $-104^{\circ} \mathrm{C}$. Gas ini mudah terpolimerisasi, terbakar dan dapat menimbulkan sambaran api (flash fire) sehingga mengakibatkan tangki pecah bahkan meledak.

c. Model Ledakan BLEVEs Kendaraan Kontainer ISO Tank

Untuk memperkirakan radius ledakan digunakan model ledakan BLEVEs dari kendaraan kontainer ISO Tank dengan menggunakan perangkat lunak modeling $\mathrm{ALOHA}^{\circledR}$. Secara umum formula model ALOHA yang digunakan untuk menggambarkan bahaya radiasi thermal adalah:

$$
q=E . F . T
$$

dimana

$q=$ flux radiasi thermal pada permukaan vertikal $\left(\mathrm{W} \mathrm{m}^{-2}\right.$ )

$E=$ adalah flux energi radiasi thermal pada permukaan bola api $\left(\mathrm{W} \mathrm{m}^{-2}\right)$

$F=$ Faktor geometrik

$T=$ transmisivitas atmosfir terhadap radiasi thermal

Beberapa asumsi yang digunakan dalam model adalah sebagai berikut:

\section{Data atmosferik}

- Kecepatan angin: 7 knot $(12,964 \mathrm{~km} / \mathrm{jam}$ atau 3,60 m/detik).

- Arah angin: utara ke selatan (menggambarkan kondisi pada bulan Desember 2016).

- Tutupan awan: 5/10.

- Temperatur udara: $34^{\circ} \mathrm{C}$.

- Kelembapan relatif: $75 \%$.

- Kekasaran permukaan: wilayah terbuka.

\section{Kekuatan Sumber}

- $\quad$ Diameter Tangki: 2,24 m.

- Panjang Tangki: 6,096 m.

- Volume Tangki: 24.000 liter.

- Wujud isi di dalam tangki: Cairan.

- Persentase isi tangki: $80 \%$ penuh.

- Massa kimiawi di dalam Tangki: 12,1 Ton (Etilena) - 13,3 Ton (Butadiena).

- Massa yang berubah menjadi bola api: $80 \%$

- Diameter bola api: 120 meter (Etilena) 123 meter (Butadiena), dengan durasi terbakar: 9 detik.

- $\quad$ Panjang api: 49 meter (Etilena) - 51 meter (Butadiena).

Tabel 2. Efek radiasi termal bagi personil ${ }^{(13)}$

\begin{tabular}{cl}
$\begin{array}{c}\text { Radiasi Termal } \\
\left(\mathrm{kW} / \mathrm{m}^{2}\right)\end{array}$ & \multicolumn{1}{c}{ Efek Bagi Personil } \\
\hline$<4$ & $\begin{array}{l}\text { Tidak ada efek serius } \\
\text { Kematian } 50 \% \text { setelah } \\
\text { terpapar } 80 \text { detik pada } \\
\text { level 12,5 }\end{array}$ \\
& $\begin{array}{l}\text { Luka bakar derajat dua } \\
\text { setelah } 8 \text { detik pada } \\
\text { level } 37,5 ; \\
\end{array}$ \\
& Kematian 100\% setelah \\
& 20 detik pada level 37,5 \\
& Kematian seketika \\
\hline
\end{tabular}




\section{Zona ancaman}

- Ancaman yang dimodelkan: radiasi termal dari bola api.

- Zona merah $\left(37,5 \mathrm{~kW} / \mathrm{m}^{2}\right): 127$ meter (Butadiena) - 128 meter (Etilena).

- Zona oranye $\left(12,5 \mathrm{~kW} / \mathrm{m}^{2}\right): 236$ meter.
- Zona kuning $\left(4 \mathrm{~kW} / \mathrm{m}^{2}\right): 415$ meter.

- Penjelasan untuk efek radiasi termal dari tiap zona ancaman disajikan pada Tabel 2. Gambaran luas area terdampak dari skenario ledakan disajikan pada Tabel 3.

Tabel 3. Luas area terdampak bencana ledakan gas skenario BLEVEs untuk gas Etilena dan Butadiena pada transporter ISO Tank pada jalan provinsi dan jalan tol Serang-Merak

\begin{tabular}{|c|c|c|c|c|c|}
\hline \multirow[b]{2}{*}{ No } & \multirow[b]{2}{*}{ Kecamatan } & \multicolumn{3}{|c|}{ Luas Area Terdampak Ledakan (Ha) } & \multirow[b]{2}{*}{ Total } \\
\hline & & $\begin{array}{c}\text { Tingkat Bahaya } \\
\text { Tinggi } \\
\text { (Merah) }\end{array}$ & $\begin{array}{c}\text { Tingkat Bahaya } \\
\text { Sedang } \\
\text { (Oranye) }\end{array}$ & $\begin{array}{l}\text { Tingkat Bahaya } \\
\text { Rendah } \\
\text { (Kuning) }\end{array}$ & \\
\hline 1. & Binuang & 0.36 & 2.03 & 7.92 & 10.31 \\
\hline 2. & Bojonegara & 128.45 & 110.30 & 181.60 & 420.35 \\
\hline 3. & Cikande & 154.90 & 129.26 & 208.73 & 492.89 \\
\hline 4. & Ciruas & 43.13 & 36.60 & 65.42 & 145.14 \\
\hline 5. & Kibin & 95.56 & 83.24 & 140.30 & 319.10 \\
\hline 6. & Kragilan & 143.62 & 121.47 & 190.92 & 456.01 \\
\hline 7. & Kramatwatu & 268.79 & 215.58 & 336.34 & 820.71 \\
\hline \multirow[t]{2}{*}{8.} & Pulo Ampel & 338.48 & 261.53 & 373.43 & 973.44 \\
\hline & Total & $1,173.29$ & 960.00 & $1,504.65$ & $3,637.94$ \\
\hline
\end{tabular}

Hasil pemodelan dengan menggunakan skenario BLEVEs di sepanjang jalur transporter disajikan pada Gambar 1 dan Gambar 2.

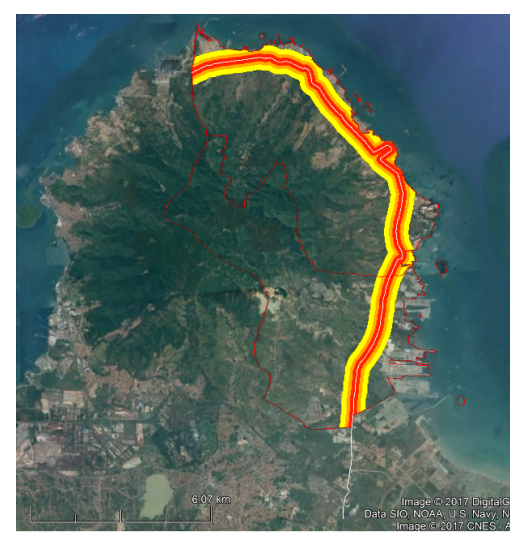

Gambar 1. Model ALOHA® potensi bahaya bencana industri skenario BLEVEs gas Etilena dan Butadiena pada transporter ISO Tank pada Jalur Jalan Provinsi Bojonegoro - Merak.

Berdasarkan hasil pemodelan diperoleh zona bahaya tinggi, sedang dan rendah baik di sepanjang jalur jalan Provinsi segmen SerangMerak dan jalur jalan provinsi dan tol sebagai berikut:

a. Tingkat bahaya tinggi (zona merah) - jarak dari as jalan 127 meter ( $37,5 \mathrm{~kW} / \mathrm{m}^{2}$ ). Dampak yang ditimbulkan adalah kematian korban secara seketika.

b. Tingkat bahaya sedang (zona oranye) jarak dari as jalan 236 meter $(12,5-37,5$ $\mathrm{kW} / \mathrm{m}^{2}$ ). Dampak yang ditimbulkan berupa Luka bakar derajat 2 dalam 8 detik, kematian $100 \%$ apabila korban tidak ditangani dalam 20 detik.

c. Tingkat bahaya rendah (zona kuning) jarak dari as jalan 416 meter (4 - 12,5 $\mathrm{kW} / \mathrm{m}^{2}$ ). Dampak yang ditimbulkan berupa kematian apabila korban tidak ditangani dalam 80 detik.

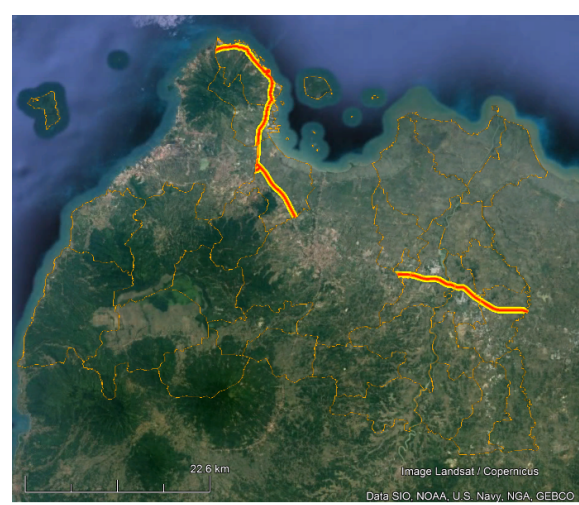

Gambar 2. Model ALOHA® potensi bahaya bencana industri skenario BLEVEs untuk gas Etilena dan Butadiena pada transporter ISO Tank pada Jalan Provinsi dan Tol Serang Merak.

\subsection{Analisis Kerentanan Sosial}

\subsubsection{Kepadatan Penduduk}

Klasifikasi kerentanan kepadatan penduduk dibagi menjadi 3 yaitu kerentanan tinggi (jika kepadatan $>10 \mathrm{jiwa} / \mathrm{ha}$ ); kepadatan sedang (jika kepadatan 5-10 jiwa/ha); dan kepadatan rendah (jika kepadatan <5 jiwa/ha). Dari Gambar 3A, nampak bahwa wilayah dengan kerentanan tinggi 
terkonsentrasi pada sisi timur Kabupaten Serang yang umumnya merupakan kawasan industri.

\subsubsection{Rasio Jenis Kelamin}

Dari hasil analisis data diketahui bahwa seluruh desa di Kabupaten Serang memiliki kerentanan rasio jenis kelamin rendah (Gambar
3B). Hal ini tergambar dari kenyataan bahwa jumlah penduduk laki-laki lebih dominan dibandingkan penduduk perempuan di seluruh desa di Kabupaten Serang. Penduduk laki-laki dianggap lebih mampu menyelamatkan diri dibandingkan penduduk perempuan.
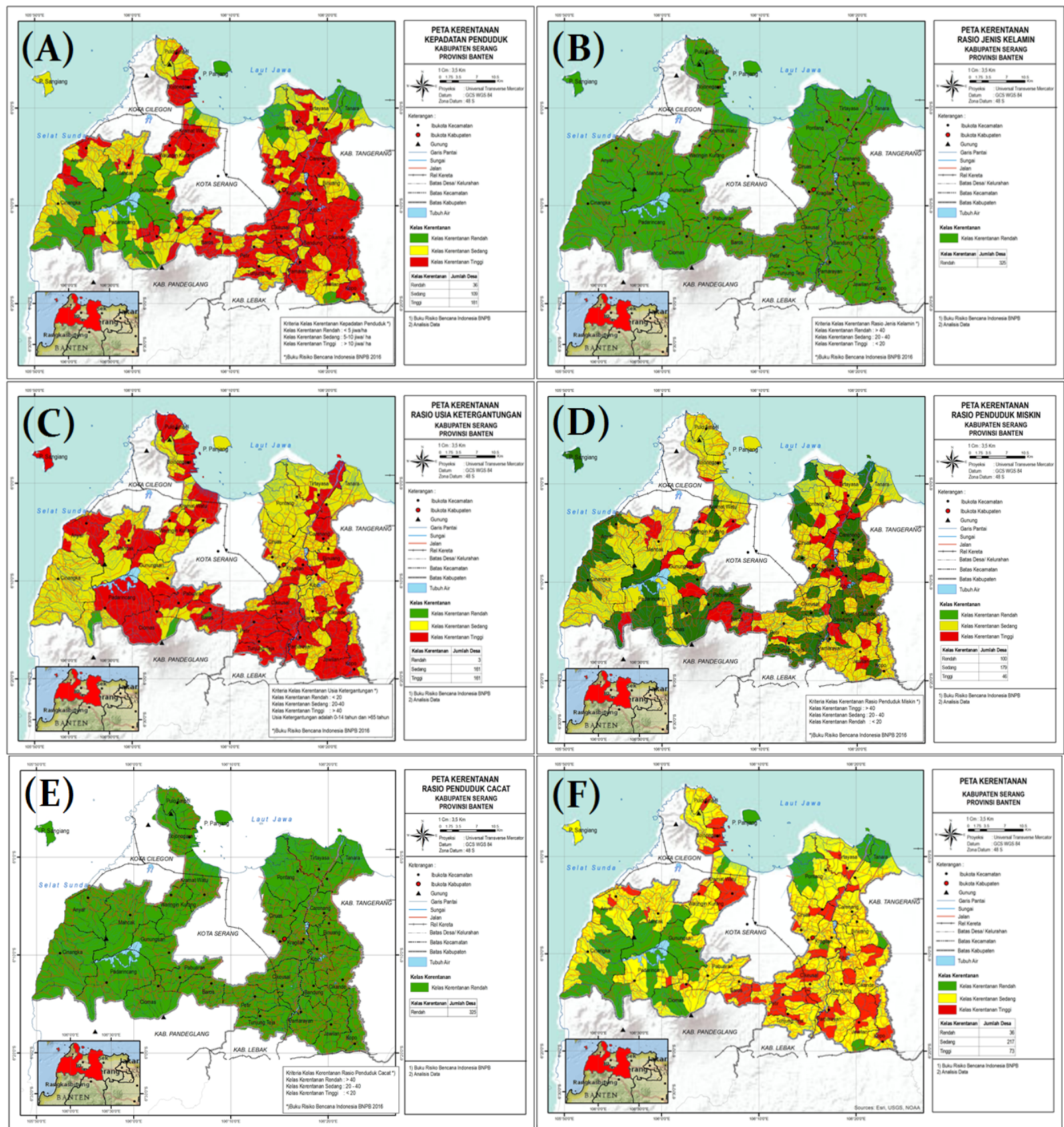

Gambar 3. A) Peta kerentanan kepadatan penduduk di Kabupaten Serang; B) Peta kerentanan rasio jenis kelamin di Kabupaten Serang; C) Peta kerentanan rasio usia ketergantungan di Kabupaten Serang; D) Peta kerentanan rasio penduduk miskin di Kabupaten Serang; E) Peta kerentanan rasio penduduk cacat di Kabupaten Serang; F) Peta kerentanan sosial di Kabupaten Serang.

\subsubsection{Rasio Usia Ketergantungan}

Rasio usia ketergantungan menunjukkan perbandingan antara jumlah penduduk usia tidak produktif terhadap penduduk usia produktif. Usia produktif dipadang sebagai kelompok usia yang mampu menyelamatkan diri saat terjadi bencana transportasi bahan industri. Di Kabupaten Serang 161 desa tergolong kerentanan tinggi, 161 desa 
kerentanan sedangkan tiga desa lainnya kerentanan rendah (Gambar 3C).

\subsubsection{Rasio Penduduk Miskin}

Secara umum, kerentanan ekonomi masyarakat Kabupaten Serang termasuk kategori sedang. Dari analisis rasio penduduk miskin; 100 desa tergolong kerentanan rendah, 179 desa tergolong kerentanan sedang, dan 48 desa tergolong dalam kerentanan tinggi (Gambar 3D).

Kerentanan ekonomi menujukkan kemampuan masyarakat untuk membangun kembali infrastruktur ekonominya setelah bencana. Semakin besar rasio penduduk miskin terhadap penduduk tidak miskin, semakin besar kerentanannya. Demikian juga sebaliknya.

\subsubsection{Rasio Penduduk Cacat}

Penduduk cacat dipandang sebagai kelompok penduduk yang sulit untuk menyelamatkan dirinya sendiri saat terjadi bencana. Semakin besar rasio penduduk cacat semakin tinggi kerentanannya. Dari hasil analisis kerentanan, seluruh desa di Kabupaten Serang memiliki kelas kerentanan rendah (Gambar 3E).

\subsubsection{Kerentanan Sosial}

Dengan metode penghitungan skor dan bobot yang terukur, didapatkan nilai kerentanan sosial untuk masing-masing desa sebagaimana disajikan pada Gambar 3F. Parameter yang paling besar konstribusinya terhadap kerentanan adalah parameter kepadatan penduduk yaitu sebesar $60 \%$. Sedangkan parameter lainnya; rasio jenis kelamin, rasio penduduk miskin, rasio usia ketergantungan dan rasio penduduk cacat, memiliki bobot kontribusi sebesar $40 \%$ secara bersama-sama.

Dari hasil analisis didapatkan bahwa sebagian besar desa di Kabupaten Serang memiliki tingkat kerentanan sedang yaitu sebanyak 217 desa. Sedangkan 36 desa memiliki kerentanan rendah dan 73 desa lainnya memiliki kerentanan tinggi.

\subsection{Analisis Risiko}

Berdasarkan hasil analisis bahaya dan analisis kerentanan sosial maka dapat dihasilkan analisis risiko akibat ledakan tangki transportasi gas B3 yang diperlihatkan dalam bentuk peta risiko seperti disajikan pada Gambar 4. Untuk skenario ledakan BLEVEs pada transporter ISO tank, risiko diperhitungkan di sepanjang jalan Provinsi dan Jalan Tol Serang Merak.

Berdasarkan hasil analisis risiko dapat dihitung luas area permukiman terdampak ledakan transporter ISO Tank Industri, dengan total luas area terdampak ledakan tingkat bahaya tinggi, sedang dan dan rendah. Hasil analisis disajikan pada Tabel 4 .

Tabel 4. Area permukiman terdampak ledakan transporter ISO Tank industri pada skenario BLEVEs

\begin{tabular}{|c|c|c|c|c|}
\hline \multirow{4}{*}{ No. } & \multirow{4}{*}{ Kecamatan } & \multicolumn{3}{|c|}{ Luas Area Permukiman Terdampak Ledakan Transporter ISO Tank (Ha) } \\
\hline & & Tinggi & Sedang & Rendah \\
\hline & & \multicolumn{3}{|c|}{ Paparan Radiasi Thermal Ledakan Skenario BLEVEs } \\
\hline & & $\left(>37,5 \mathrm{~kW} / \mathrm{m}^{2}\right)^{\mathrm{a}}$ & $\left(12,5-37,5 \mathrm{~kW} / \mathrm{m}^{2}\right)^{\mathrm{b}}$ & $\left(4-12,5 \mathrm{~kW} / \mathrm{m}^{2}\right)^{\mathrm{c}}$ \\
\hline 1. & Binuang & 0.90 & & 0.43 \\
\hline 2. & Cikande & 19.24 & 8.07 & 10.77 \\
\hline 3. & Kibin & 26.20 & 14.64 & 14.85 \\
\hline 4. & Kragilan & 26.90 & 17.24 & 17.36 \\
\hline 5. & Ciruas & 3.53 & 0.03 & 0.79 \\
\hline 6. & Kramawatu & 50.41 & 15.66 & 21.35 \\
\hline 7. & Bojonegoro & 16.41 & 37.32 & 24.65 \\
\hline 8. & Pulo Ampel & 30.13 & 47.96 & 19.32 \\
\hline & Total & 173.73 & 140.92 & 109.52 \\
\hline
\end{tabular}

Keterangan: Paparan radiasi thermal dari ledakan pada skenario BLEVEs memiliki dampak: a) kematian seketika; b) Luka bakar derajat 2 dalam 8 detik, kematian 100\% bila tidak ditangani dalam 20 detik; c) kematian bila tidak ditangani dalam 80 detik. 


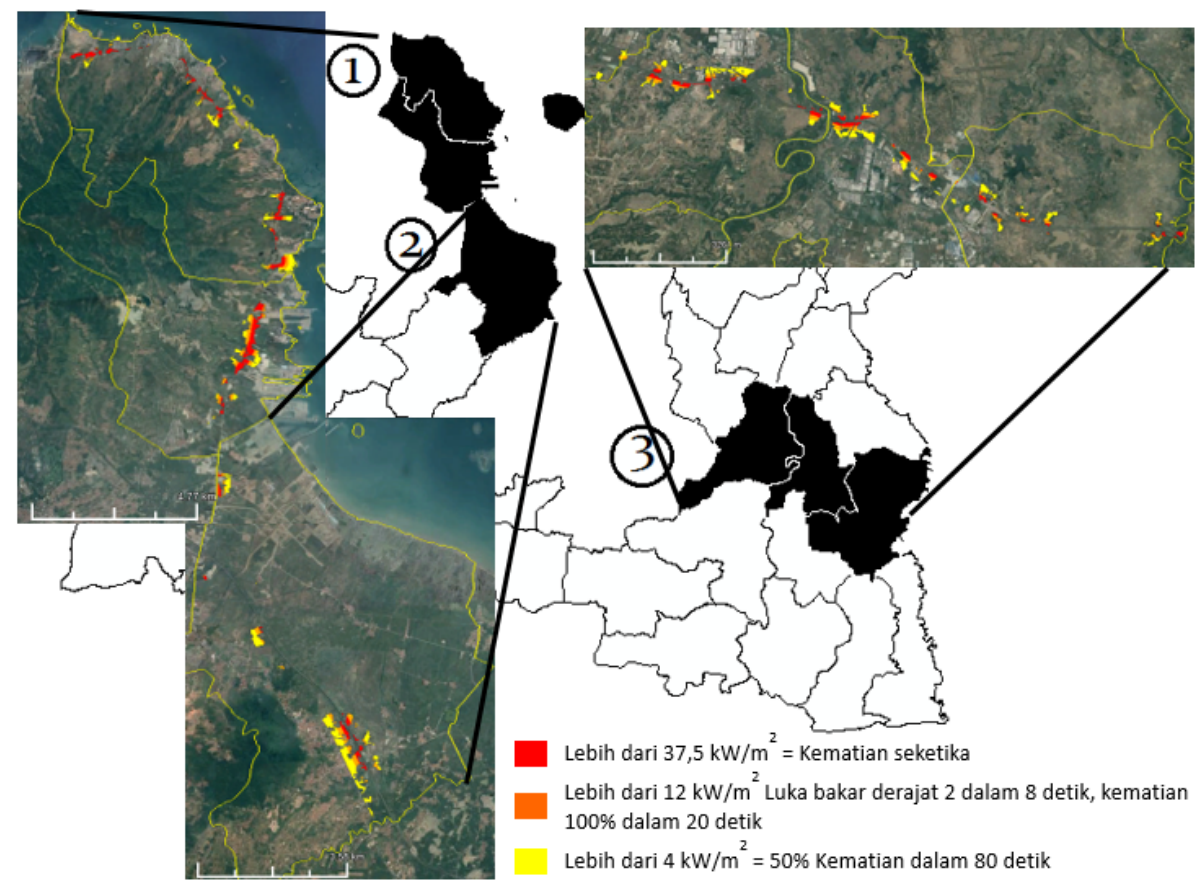

Gambar 4. Gambaran risiko bencana ledakan ISO Tank pada kawasan permukiman di sepanjang jalan Provinsi dan jalan tol Jakarta-Merak

\subsection{Upaya Mitigasi}

Pada transportasi bahan berbahaya menggunakan ISO Tank, salah satu aspek penting yang dapat mengurangi potensi ledakan adalah meningkatkan ketahanan tangki dari tumbukan dengan menggunakan dinding ganda berinsulasi vacuum $^{(9)}$. ISO Tank dengan spesifikasi seperti ini umum digunakan di Amerika Serikat dan beberapa negara di Eropa.

\section{KESIMPULAN}

a. Berdasarkan hasil pemodelan ledakan tangki transportasi gas Etilena dan Butadiena menggunakan ISO Tank dengan skenario BLEVEs, diperoleh 3 zona bahaya yaitu: bahaya tinggi, sedang dan rendah di sepanjang jalur jalan Provinsi segmen Serang-Merak dan jalur jalan provinsi dan tol sebagai berikut:

- Tingkat bahaya tinggi (zona merah) - jarak dari as jalan 127 meter (> $37,5 \mathrm{~kW} / \mathrm{m}^{2}$ ). Dampak yang ditimbulkan adalah kematian seketika.

- Tingkat bahaya sedang (zona oranye) jarak dari as jalan 236 meter $(12,5-37,5$ $\mathrm{kW} / \mathrm{m}^{2}$ ). Dampak yang ditimbulkan berupa Luka bakar derajat 2 dalam 8 detik, kematian $100 \%$ bila tidak ditangani dalam 20 detik.

- Tingkat bahaya rendah (zona kuning) jarak dari as jalan 416 meter (4 - 12,5 $\mathrm{kW} / \mathrm{m}^{2}$ ). Dampak yang ditimbulkan berupa kematian bila tidak ditangani dalam 80 detik. b. Berdasarkan hasil analisis kerentanan didapatkan bahwa sebagian besar desa di Kabupaten Serang memiliki tingkat kerentanan sedang yaitu sebanyak 217 desa. Sedangkan 36 desa memiliki kerentanan rendah dan 73 desa lainnya memiliki kerentanan tinggi.

c. Berdasarkan hasil analisis risiko dapat dihitung luas area permukiman penduduk terdampak ledakan transporter ISO Tank untuk 3 tingkat paparan radiasi thermal sebagai berikut:

- Tingkat bahaya tinggi - luas area permukiman terdampak 173,73 Ha. Dampak yang ditimbulkan adalah kematian seketika.

- Tingkat bahaya sedang - luas area permukiman terdampak 140,92 Ha. Dampak yang ditimbulkan berupa Luka bakar derajat 2 dalam 8 detik, kematian $100 \%$ bila tidak ditangani dalam 20 detik.

- Tingkat bahaya rendah - luas area permukiman terdampak 109,52 Ha. Dampak yang ditimbulkan berupa kematian bila tidak ditangani dalam 80 detik.

\section{PERSANTUNAN}

Ucapan terima kasih kami sampaikan kepada Badan Penanggulangan Bencana Daerah (BPBD) Kabupaten Serang yang telah memberikan dukungan kerjasama, perijinan dan pendanaan dalam penelitian ini. Khususnya kepada Bapak Nana Sukmana Kusuma, SE., MM. sebagai Kepala Pelaksana BPBD 
Kabupaten Serang untuk tahun 2017. Ucapan Terima kasih kami sampaikan pula kepada para Manajer Health Safety and Environmental (HSE) dari PT. BASF, PT. Styrindo Mono Indonesia (SMI), PT. Polychem Indonesia dan PT. Sulfindo Adiusaha yang bertempat di zona Industri Pulo Ampel, Kabupaten Serang.

Penelitian ini merupakan bagian dari kerjasama antara Pusat Teknologi Reduksi Risiko Bencana BPPT dan Badan Penanggulangan Bencana Daerah Kabupaten Serang tahun anggaran 2017, dimana hasilnya diharapkan dapat digunakan sebagai Master Plan dan Action Plan Kebencanaan di Kabupaten Serang.

\section{DAFTAR PUSTAKA}

1. United Nation International Strategy for Disaster Reduction, (2009), UNISDR Terminology on Disaster Risk Reduction, Published by UNISDR, Geneve, Switzerland.

2. Badan Nasional Penanggulangan Bencana, (2008), Peraturan Kepala Badan Nasional Penanggulangan Bencana No. 4 Tahun 2008 tentang Pedoman Penyusunan Rencana Penanggulangan Bencana.

3. International Federation of Red Cross and Red Crescent Societis, Technological hazards - industrial accidents, Available from http://www. ifrc.org/en/whatwedo/disasterma nagement/aboutdisasters/definitionofhazard/ industrial-accidents/

4. Krejsa, P., (1997), International Decade for Natural Disaster Reduction, IDNDR Early Warning Programe, Report on Early Warning for Technological Hazards. Austrian research Centre Seibersdorf, IDNDR Secrertariat, United Nation, Geneva.

5. McClain, S., (2018), Words into Action Guidelines, Man-made and Technological Hazards, Practical considerations for Addressing Man-made and Technological Hazards in Disaster Risk Reduction, UNSIDR.
6. Baheramsyah, A., Pitana, T., Widodo, A., Widyastuti, T. D., (2013), Studi Awal Pemetaan Risiko Bencana Industri Di Indonesia, PSKBPI-ITS, Seminar Nasional Riset Kebencanaan, 8-10 Oktober 2013, Mataram.

7. BPBD Kabupaten Serang, (2017), Master Plan dan Action Plan Kebencanaan Kabupaten Serang.

8. Prihartanto, Wisyanto, C., Putra, A. P, Prawiradisastra, F., Yuilana, D. K., Patrianto, H., Sittadewi, E. H., Raharjo, A. P., Rahayu, B., Marwanta, B., Rovara, O., Riyandari, R., Astuty, T dan Tedjakusuma, (2013), Rekomendasi untuk Pengurangan risiko Bencana Kegagalan Teknologi Kawasan Industri Kota Cilegon, PTRRB-BPPT.

9. Casal, J., (2017), Evaluation of the Effects and Consequences of Major Accidents in Industrial Plants. $2^{\text {nd }}$ Edition. Technology \& Engineering, Elsevier, 570pp.

10. VI'lchez ,J.A., Sevilla, S., Montiel, H., Casal, J., (1995), Historical analysis of accidents in chemical plants and in the transportation of hazardous materials, Journal of Loss Prevention in the Process Industries. 8(2): 87-96.

11. A. Oggero, R.M. Darbra, M. Muñoz, E. Planas, J. Casal, (2006), A survey of accidents occurring during the transport of hazardous substances by road and rail, Journal of Hazardous Materials. 133(1-3): 17.

12. Amri, R. M., Yulianti, G., Yunus, R. Wiguna, S., Adi, A. W., Ichwana, A. N., Randongkir, R. E., Septian, R. T., (2016), Risiko Bencana Indonesia, Badan Nasional Penanggulangan Bencana, Dir. Pengurangan Risiko Bencana, BNPB

13. Marsden, E., (2017), Consequence modelling: overview of hazards, Available from https://risk-engineering.org/static/PDF/ slides-conseq-hazards.pdf, (viewed Mei 1, 2018). 